\title{
7
}

\section{Sustainable Building in Malaysia: The Development of Sustainable Building Rating System}

\author{
Ar Zuhairuse MD Darus ${ }^{1}$ and Nor Atikah Hashim² \\ ${ }^{1}$ Department of Architecture, Faculty of Engineering and Built Environment, \\ University Kebangsaan Malaysia \\ ${ }^{2}$ Department of Quantity Surveying, Faculty of Engineering and Technology, \\ INTI International University \\ Malaysia
}

\section{Introduction}

The Malaysian building industry has over the years been developing and working towards a more sustainable and green architecture. The needs for SBRS (Sustainable Building Rating System) become more apparent with the increasing demand from building end-user for Green rated building. This is also support by objectives of many companies today where good corporate social responsibility (CSR) calls for them to support environmental friendly including their office premises.

The issue of Sustainable Building Rating System in Malaysian building industry is still new. Even though Green Building Index has been developed, but the application is only to new building. There is no study done on the application of SBRS to existing building yet. Thus, Knowledge and understanding on how the Sustainable Building Rating System (SBRS) can increase their building performance and prolong the building life span among the actors in Malaysian building industry are very low. Shafii and Othman (2005) reveal that one of the major barriers holding back the development of sustainable building in Southeast Asia is the lack of awareness of sustainability issues in related to profession. The survey conducted by Shari, Jaafar et al (2007) also reveals that the Malaysian building industry players have 'little' knowledge on sustainable building assessment, rating and labelling system. Due to this, many offices building in Malaysia lay to claim for sustainability. The building maintenance and operation cost increase drastically every year. The building condition deteriorate and this situation will lead to the lost of rental income by the owner.Tenant of an office building will go for a better building environment for their company good reputation. Even though the capital investment for sustainable building is very high, but the long term of operation and maintenance cost is very low. Before the system can be developed, there question need to be addressed such as:

i. How do the building experts evaluate building sustainability effectively using SBRS tools?

ii. What are the available SBRS tools that could be used in Malaysia? 
iii. What are the current scenarios of Malaysian building industry?

iv. What are the effects of implementing Sustainable Building Rating System Tools in Malaysia?

The first section reviews available SBRS tools worldwide to select the appropriate tools to be tested. It is also analysed the Malaysian building industry issues to identified the implementation problems arise. The second section in this chapter, report the experience of conducting assessment of selected Sustainable Building Rating System on the Low Energy Office (LEO) building. It is also describes the three structures of comparison analysis on the aspect that is considered in the assessment- Theoretical Comparison Analysis, The Evaluation Comparison Analysis and Overall Comparison. Expert review on the assessment are carried out to validate the result. The third section analyses the expert review on Green Mark and SBTool. The fourth section analyses in-depth interviews with the building expert. This section describe the interviews result in descriptive form.

\section{Review of various SBRS}

Currently, several environmental methodologies and methods for evaluating environmental performance of buildings are being developed. In a global scale it is worth mentioning SB (Sustainable Building) Tool, formerly known as GB Tool (Green Building Tool) which is an international project coordinated from Canada, LEED (Leadership in Energy and Environmental Design) a method developed in the USA with a world wide application and CASBEE (Comprehensive Assessment System for Building Environmental Efficiency), a method developed in Japan. In Europe, some of the most frequently used include BREEAM (Building Research Establish Environmental Assessment Method) in the UK and it is worth mentioning the HQE (High Environmental Quality) developed in France during the last decade and the VERDE method developed recently in Spain (Maria Sinou, 2006).

The growth and use of buildings' environmental performance assessment methodologies, is considered to contribute greatly to the integration of methods and practices favouring sustainability in the building sector. The methods that have been developed worldwide are built upon various principles and different evaluation items, data and criteria. However, most of the tools do not take into consideration the lifetime parameters. The assessment they measures is based on original conditions and characteristic, whereas the modification of the building elements' attributes are not taken into accounts.

\section{The comparison}

The environmental assessment methodologies covers in this literature include SBTool, Green Mark, BREEAM, CASBEE (Comprehensive Assessment System for Building Environmental Efficiency), Green Star and LEED (Leadership in Energy and Environment Design (launched in 1998). This summarizes the approach used by each of these methods and includes a quick comparison of the environmental standards demanded to meet each rating. A common theme of each assessment method is the reliance on existing building regulations and other third party standards. As any environmental assessment methodology needs to cover such a wide range of issues there is no other way that a system could remain up to date without significant initial investment and continual extensive maintenance. Also, reliance on existing third-party standards or regulations lends credibility to the system, 
especially among sceptics. As well as comparing the scores and rating levels in each of the schemes, the major differences in the processes have been investigated. The major differences between the schemes have been highlighted in table 1 .

For the purposes of this review, 'sustainable building rating systems' is defined as tools that examine the performance or expected performance of a 'whole building' and translate that examination into an overall assessment that allows for comparison against other buildings. For a rating system to add value to the sustainable design and/or operation of a building, it must offer a credible, consistent basis for comparison, evaluate relevant technical aspects of sustainable design, and not be over-burdensome to implement and communicate. In order to identify the most applicable rating systems for the case study, the following review approach is used:

1. Identification of sustainable building rating systems

2. Screening analysis of rating systems to limit review to most applicable systems.

3. Identification of case study drivers for a credible rating system (review criteria)

4. Data collection on applicable rating systems for comparative review.

5. Review of the merits of applicable rating systems as they apply to the case study.

As each of these rating systems are being researched, it became evident that many of them do not fit the sustainable building rating system needs of case study. Therefore screening criteria are identified in order to concentrate the review on the systems that have the greatest potential of addressing case study needs. The screening criteria include:

- Relevance: Does the rating system provide a "whole building evaluation" rather than an evaluation of an individual design feature?

- Measurable: Does the rating system use measurable characteristics to demonstrate the extent of sustainable design incorporated into the building?

- Applicability: Can the rating system be used on all of the types of commercial buildings or office buildings?

- Availability: Is the rating system easily adaptable to the Malaysian market or currently available for use in the Malaysian market?

\begin{tabular}{|l|c|c|c|c|}
\hline \multicolumn{5}{|c|}{ Rating Systems Screening Criteria Scores } \\
\hline $\begin{array}{l}\text { Rating System } \\
\text { Name }\end{array}$ & Relevance & Measurable & Applicability & Availability \\
\hline BREEAM & $\sqrt{ }$ & $\sqrt{ }$ & $\sqrt{ }$ & \\
\hline LEEDS & $\sqrt{ }$ & $\sqrt{ }$ & $\sqrt{ }$ & \\
\hline SBTool & $\sqrt{ }$ & $\sqrt{ }$ & $\sqrt{ }$ & $\sqrt{ }$ \\
\hline GREENSTAR & $\sqrt{ }$ & $\sqrt{ }$ & $\sqrt{ }$ & \\
\hline CASBEE & $\sqrt{ }$ & $\sqrt{ }$ & $\sqrt{ }$ \\
\hline GREENMARK & $\sqrt{ }$ & & & \\
\hline
\end{tabular}

Table 2. Rating Systems Screening Criteria Scores 
From table 2, Green Mark and SBTool are selected based on the availability criteria scores from the screening table. The nature of the tools that can be seen in table 3 is the criteria for selection of both tools.

\begin{tabular}{|c|c|}
\hline Green Mark & SBTool \\
\hline 1. The structure is simple and easy. & $\begin{array}{l}\text { 1. The structure is comprehensive and explore } \\
\text { various result. }\end{array}$ \\
\hline $\begin{array}{l}\text { 2. The issues suit to local context as } \\
\text { Singapore and Malaysia are similar in } \\
\text { climate and social aspect. }\end{array}$ & $\begin{array}{l}\text { 2. The issues and benchmark can be } \\
\text { customised to local context }\end{array}$ \\
\hline $\begin{array}{l}\text { 3. The scores easily derives from the } \\
\text { points allocated for each issues. }\end{array}$ & $\begin{array}{l}\text { 3. The scores automatically derives from the } \\
\text { programmed tools. Save time. }\end{array}$ \\
\hline $\begin{array}{l}\text { 4. The criteria of assessment are straight } \\
\text { forward and easy to identify. }\end{array}$ & $\begin{array}{l}\text { 4. The criteria and benchmark are } \\
\text { comprehensive and allow the assessor to } \\
\text { explore various result. } \\
\text { It is also allow improvement of local practice } \\
\text { to consider on the non compliance criteria. } \\
\text { This apply to absent of data such as embodied } \\
\text { energy of material use in Malaysia. }\end{array}$ \\
\hline $\begin{array}{l}\text { 5. Energy efficiency is the most } \\
\text { important issues }\end{array}$ & $\begin{array}{l}\text { 5. Comprehensive and consider all aspect as } \\
\text { framework. }\end{array}$ \\
\hline $\begin{array}{l}\text { 6. Easy to understand the evaluation } \\
\text { procedure as information are available } \\
\text { through website. }\end{array}$ & $\begin{array}{l}\text { 6. Easy to understand the evaluation } \\
\text { procedure as information are available } \\
\text { through website }\end{array}$ \\
\hline
\end{tabular}

Table 3. The evaluation comparison of Green mark and SBTool

\section{Drivers for sustainable design and use of a rating system}

In order to establish review criteria for the rating systems that is consistent with Malaysian building industry's drivers for applying a rating system, government policy, Acts, program goals related to the design and operation of sustainable buildings are identified and summarized in this section.

Those drivers include:

- MS1525 being mandatory and applied to LEO building as a showcase for energy efficiency. 
- $\quad$ Adaptation of Conquas as Qlassic by CIDB.

- Renewable energy promotion, programme and research and development.

- Quality mindset

- $\quad$ ISO 9001 certification

\section{The Malaysian building industry issues}

The possible factors of Sustainable Building Rating System success implementation will be depending on the following factors:

\subsection{Government support}

The Ministry of Energy, The Energy Commission, MIDA (The Malaysian Industry Development Authority), promotes renewable energy resources through research and development of biomass renewable energy, mini hydro project, solar energy, infrastructure development for renewable energy and support renewable energy industry and drive market development for renewable energy. Malaysian government built the first energy efficiency building in 2005 as a showcase of MS 1525 to the building industry on the low energy office building. The building is known as LEO building and occupied by KETTHA (Ministry of Energy, Green Technology \& Water).

Ministry of housing and local government (MHLG) and National Hydraulic Research Institute of Malaysia(NAHRIM) promote rainwater harvesting for residential and industrial building through research and development on the rainwater harvesting model and design. MHLG through local authority promote and enforces the rainwater harvesting legislation to make it compulsory on new development projects. Government also monitor the quality through various ISO Certification by SIRIM research and development on the sustainable issues.

\subsection{Building industry support}

Malaysian Institute of Architects(MIA) until now tries to incorporate design guidelines for Energy Efficiency i.e. clauses that point to the Malaysian code of practice MS1525 to enable adoption by local authorities to ensure minimum energy performance standards in residential and commercial. CIDB enforces Quality certification for building industry players and projects to monitor the quality control of the building industry by adapting CONQUAS (from BCA Singapore) as QLassic. The recent development of Green Building Index for New Building by MIA and Institute of Engineers Malaysia (IEM) enhances the implementation factors on Malaysian building. Many architects have shifted to design sustainable building recently and make the practice demanding in the Malaysian building industry market. Promotion by the building industry player on sustainable design also increase the demand for sustainable building because they create awareness to the public and end user of the building.

\subsection{Public awareness}

Awareness of sustainable development by the public has created industry drive and demand for sustainable building design in Malaysia .This will result in the increase of demand for sustainable building and more building will try to be certified with SBRS to 
compete in the market. Recycling, reduce and reuse are promoted everywhere by the government and non- government organisations and energy saving is the main achievement. Demand for energy saving equipment also increases recently because the equipment save the cost of energy bills.

\section{Theoretical comparison analysis}

The evaluative framework for environmental management approaches developed by Henrikke Baumann and Sarah J. Cowell (1999) is adapted to structure the framework of Green Mark and SBTool to represent the essence of both tools. This framework is used to give better understanding of the context structure with academically recognised terminology and methodology. The framework comprise of three aspects, generic, contextual and methodological. As we can see from the aspect table 4, under generic aspect sub for nature of approach, both of the tools are categorized as a tool for sustainable building assessment.

\subsection{Type of decision maker}

Under contextual aspect several types of decision maker can be identified as governments/authorities, companies and NGO's. Here, decision makers are using the approach and/or their results.

\subsection{Overall purpose}

The approach is used for communication purpose. It implies that the information is directed at others than oneself and the various data sources indicate that it support communication.

\subsection{Object analysed}

The object analysed identifies the focus of the decision. Ecosphere implies a focus on use of land and techno sphere focus on identifying the environmental effects associated with the building use. Green Mark and SBTool also focus on site selection and technology to increase building sustainability.

\subsection{Perspective}

Prospective approaches look forward in time and retrospective look back in time. Both approaches are used in the tools as they evaluate the previous and subsequence phases of the buildings' performance. A methodological aspect is only valid for the tool. So this aspect can be used to describe the structure of the tools.

\subsection{Investigated dimension}

Green Mark and SBTool assessment covers all the categories that are environmental, economic and social.

\subsubsection{Character of the approach}

Defined model is used under mathematical modelling. 


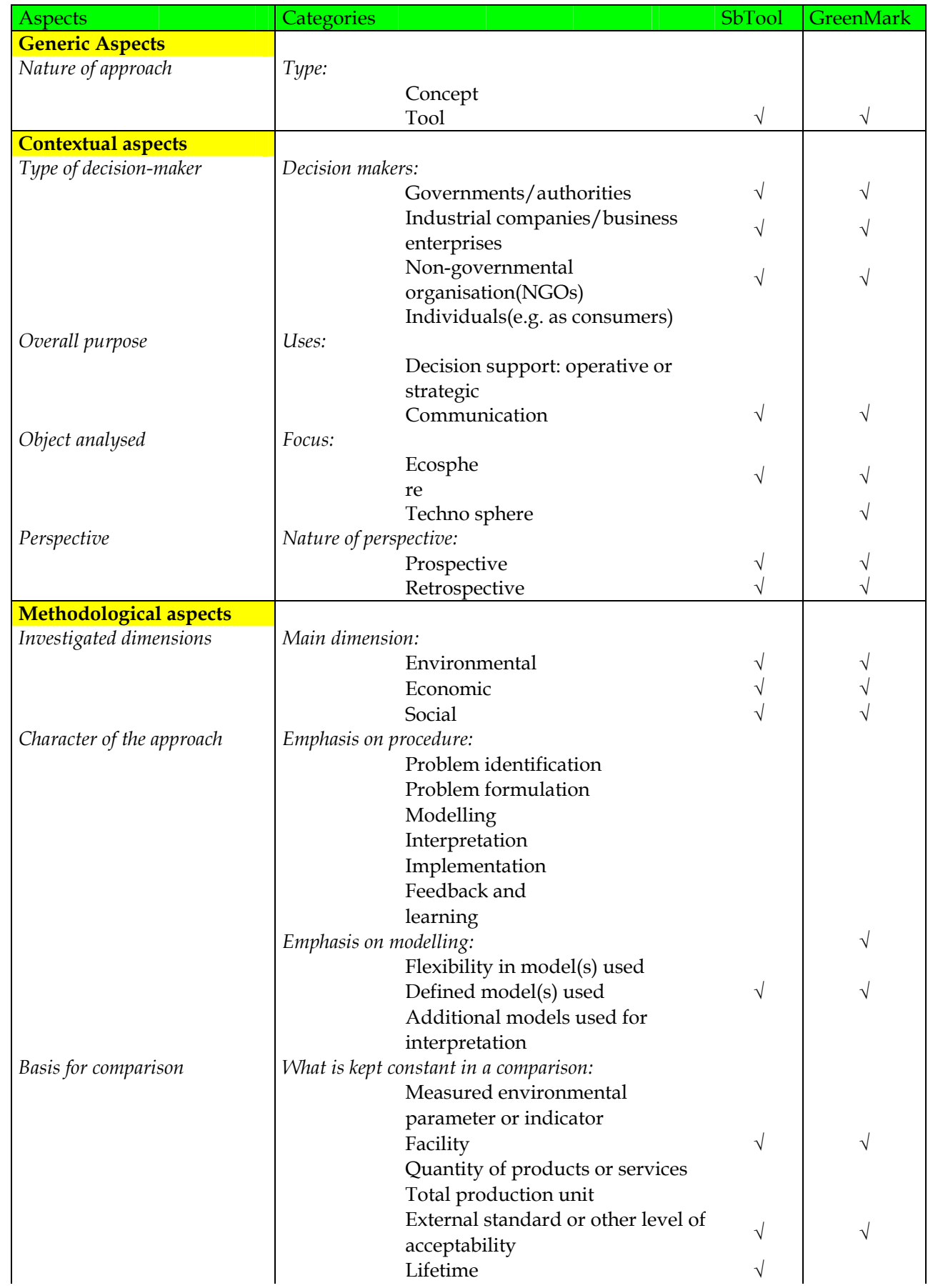




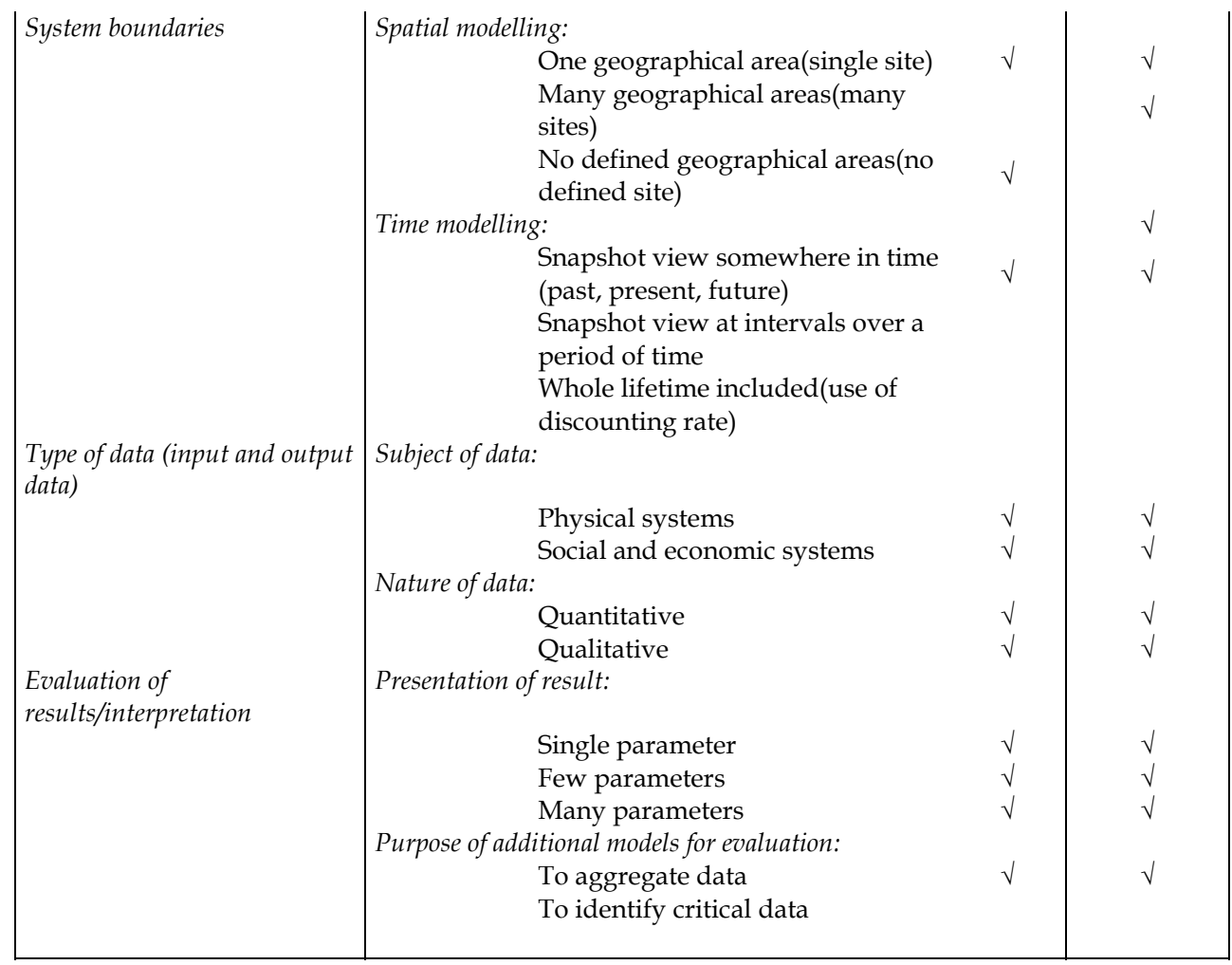

*Adopted from Henrikke Baumann and Sarah J. Cowell (1999)

Table 4. Aspect Framework of Green Mark and SBTool

\subsubsection{Basis for comparison}

The bases of comparison for the tools are facility and an external standard or other level of acceptability. Green Mark and SBTool approaches are comparing the site before and after construction.

\subsubsection{System boundaries}

Spatial modelling is used in Green Mark and SBTool as the tools only investigate one single site from the use of drawing and the content of many checklists used. Time modelling is also used as the Green Mark is not valid after three years and major renovation. This is also applied to SBTool.

\subsubsection{Type of data (input and output data)}

The data used for Green Mark and SBTool can be categorised as physical system, economic and social system because it concern on energy efficiency and matter in technological system for sustainability, e.g. solar panel, rainwater harvesting. 


\subsection{Evaluation of result/interpretation}

Both tools tend to be a mixture of qualitative and quantitative data. Output data can be in single parameter, few parameters and many parameters. The result is to aggregate data or show that certain data are particularly critical to the result by tables of main aspects and charts.

\section{The evaluation comparison analysis}

The operational work of the evaluation can be described as a means of collecting, analyzing, calculating data to get all the criteria scored from the building assessment. The performance of the objective building can finally be express with simple charts.

\subsection{Result of Green Mark}

The result of Green Mark assessment method for LEO building is 81/100. This result indicates that LEO building is certified under Green Mark Gold Plus. It greatly proves that LEO building is a sustainable building in an appropriate approach. This is due to the understanding of how the tool evaluates the building. The methods are straight forward and comes with a very comprehensive descriptions and calculations. The building are assessed twice with the presence of the building manager to verify the result. Table 5 shows the overall green Mark result for LEO building.

\begin{tabular}{|lcc|}
\hline GREEN MARK FOR LEO BUILDING & & \\
Points allocation of Green Mark Criteria & $\begin{array}{c}\text { Points } \\
\text { allocated }\end{array}$ & $\begin{array}{c}\text { Points } \\
\text { Given }\end{array}$ \\
Part 1: Energy Efficiency & & \\
1. Energy Efficiency Index & 7 & 7 \\
2. Continual Improvement for Energy Efficiency & 7 & 7 \\
3. Electrical Sub-metering & 7 & 2 \\
4. Energy Efficient Systems \& Features & 7 & 6 \\
5. Roof Top Gardens \& Landscaping & 3 & 3 \\
Sub-total & 25 & 25 \\
& & \\
Part 2: Water Efficiency & & 2 \\
1. Continual Improvement for Water Efficiency & 6 & 2 \\
2. Water Efficient Fittings & 6 & 3 \\
3. Water Efficient Irrigation and Landscaping & 3 & 7 \\
Sub-total & 15 & \\
Part 3: Building Management \& Operation & & 3 \\
1. Building Maintenance & & \\
2. Environmental Management System & 3 &
\end{tabular}


3. Building Maintenance and Operation

4

3

Guidelines

4. Preservation \& Enhancement of Landscaping

3

2

5. Public Transport Accessibility

6. Recycling

7. Occupant Health

$4 \quad 3$

Sub-total

Sub-total

Part 4: Indoor Environmental Quality and Environmental Protection

1. Effective Ventilation

2. High Frequency Ballasts

3. Luminance Level

2

4. Thermal Comfort

2

2

5. Noise Level

6. Indoor Air Quality Audit

7. Refrigerants

Sub-total

Part 5: Innovation

1. Innovation

Sub-total

85 AND ABOVE

$80 \mathrm{TO}<85$

$70 \mathrm{TO}<80$

$55 \mathrm{TO}<70$
PLATINUM

GOLD Plus

GOLD

Green Mark Award

Table 5. The Green Mark Result.

\subsubsection{Energy efficiency analysis}

From the assessment result, an average energy consumption of LEO building is $119 / \mathrm{kWh} / \mathrm{m} 2 / \mathrm{yr}$. The building is equipped with a comprehensive Building Energy Management System (BEMS) that is integrated with building Control system (BCS). BEMS monitors the building energy consumption. Integration of BEMS

Under the Energy Efficiency Index, energy consumption is monitored using the BEMS and target was set to the lower point. The average index for Leo building is $119 \mathrm{KWh} / \mathrm{m} 2 / \mathrm{yr}$. 
This is considered very good as Green Mark target for the lowest is $150 \mathrm{KWh} / \mathrm{m} 2 / \mathrm{yr}$. For Continual Improvement for energy efficiency, 2 points are given for conducting monthly energy monitoring; 2 points are given for establishing energy efficiency target at $100 \mathrm{kWh} / \mathrm{m} 2 / \mathrm{yr} .3$ points are given for establishing continual improvement plans and action. The total point is $7 / 7$.This is because there is no regional concerned in this matter as the climate is the same and the building regulation similar to Malaysia. Table 6 shows the energy efficiency result.

\begin{tabular}{|lcc|}
\hline Part 1: Energy Efficiency & Allocated & Given \\
1. Energy Efficiency Index & 7 & 7 \\
2. Continual Improvement for Energy Efficiency & 7 & 7 \\
3. Electrical Sub-metering & 7 & 2 \\
4. Energy Efficient Systems \& Features & 7 & 6 \\
5. Roof Top Gardens \& Landscaping & 3 & 3 \\
\cline { 2 - 3 } Sub-total & $\mathbf{2 5}$ & $\mathbf{2 5}$ \\
\hline
\end{tabular}

Table 6. Energy Efficiency

Under Criteria 3, Electrical Sub-Metering, 2 points are given for sub-meter used to monitor energy consumption of key building services. Criteria 4, Energy Efficient Systems \& Features covers for energy efficient features used, energy efficient lightings, air-conditioning system, lifts, day lighting and natural ventilation. Additional points are given for extensive usage of those features. Three (3) points are given to Roof top Gardens \& Landscaping as the building had a proper maintenance of the garden and landscaping.

\subsubsection{Water efficiency analysis}

As directed by the management, a plan to improve water conservation in the building has been provided. Sub metering is available to quantify savings and some automatic flushing system have been converted to manual flushing (auto stopped) to avoid unnecessary flushing caused by the motion sensors.

\begin{tabular}{|lcc|}
\hline Part 2: Water Efficiency & Allocated & Given \\
1. Continual Improvement for Water Efficiency & 6 & 2 \\
2. Water Efficient Fittings & 6 & 2 \\
3. Water Efficient Irrigation and Landscaping & 3 & 3 \\
\cline { 2 - 3 } Sub-total & $\mathbf{1 5}$ & $\mathbf{7}$ \\
\hline
\end{tabular}

Table 7. Water Efficiency

Points awarded to LEO building on water efficiency are low because only part of the water efficiency target are followed and practiced. For the first parameter, Continual Improvement for water efficiency, only 2 points are given for establishing water conservation improvement plans. Only parts of the toilets are fitted with automatics water taps and automatics flushing system under the second parameters. For water Efficient Irrigation and Landscaping, full points are given for the use of rainwater for irrigation and installing 
automatic irrigation system for sky garden. Rainwater harvesting system is used for landscape irrigation. Table 7 show the water efficiency result.

\subsubsection{Building management and operation}

LEO (Low Energy Office) building is owned by Malaysian government and comprehensively maintained by the Public Work Department (PWD)). Another party which responsible to look into the maintenance input and monitoring of the building is Pusat Tenaga Malaysia (PTM). Environmental Management System has not been established in the building. Post occupancy survey and feedback have been conducted. Daily environment monitoring, feedback complaint and corrective actions have been implemented to ensure the users comforts and safety are maintained. Building end user guidelines / pamphlets are available and distributed among the occupants. Awareness training is available. Energy monitoring and guidelines are established. Guideline for refurbishment is not available but the activities is controlled and monitored by the building manager to ensure the energy efficient features and objectives are maintained. Table 8 show the Building Management and operation result.

\begin{tabular}{|lcc|}
\hline Part 3: Building Management \& Operation & Allocated & Given \\
1. Building Maintenance & 3 & 3 \\
2. Environmental Management System & 8 & 3 \\
3. Building Maintenance and Operation & 4 & 3 \\
Guidelines & & \\
4. Preservation \& Enhancement of Landscaping & 3 & 2 \\
5. Public Transport Accessibility & 1 & 1 \\
6. Recycling & 4 & 3 \\
7. Occupant Health & 2 & 1 \\
Sub-total & 25 & $\mathbf{1 6}$ \\
\hline
\end{tabular}

Table 8. Building Management and Operation

\subsubsection{Indoor environmental quality and environmental protection}

The score for this category is quite good except for the indoor air quality audit is zero(Table 9). This is due to non audit has been performed in the building under this category. The BCS and BEMS system controls the criteria 1 and 2 and all lighting in the office area used fluorescent luminaries with high frequency electronic ballast. Luminance level and thermal comfort follows the MS1525 and consequently, it is easy to measure the level as the building is designed according to MS1525 requirement.

Noise level is at the minimum as there is no air-condition chillers. Low noise is due to low capacity and variable speed of the fans and pumps. Room partitions are sandwiched with 
mineral wool for acoustic and fire control. Furthermore, the air condition distribution system is designed to have low resistance thus reduce the noise level. No refrigerant is used as the supply is from district cooling.

\begin{tabular}{|lcc|}
\hline $\begin{array}{l}\text { Part 4: Indoor Environmental Quality and Environmental } \\
\text { Protection }\end{array}$ & Allocated & Given \\
1. Effective Ventilation & 2 & 2 \\
2. High Frequency Ballasts & 2 & 2 \\
3. Luminance Level & 2 & 2 \\
4. Thermal Comfort & 2 & 2 \\
5. Noise Level & 2 & 2 \\
6. Indoor Air Quality Audit & 2 & 0 \\
7. Refrigerants & 3 & 3 \\
Sub-total & $\mathbf{1 5}$ & $\mathbf{1 3}$ \\
\hline
\end{tabular}

Table 9. Indoor Environmental Quality and Environmental Protection

\subsubsection{Innovation}

Under innovation part (Table 10), 1 point is given for rainwater harvesting, cool paints inside the buildings, solar PV (renewal energy) for water wall system as part of education and demonstration, sky garden, skylight in the atrium, double roof at rooftop for additional shading \& maximise use of space. 2 points are given to motion sensor for lightings, natural ventilated atrium, energy saving office equipment and energy efficient designed features.

Additional marks are also considered for efficient construction methods (use of IBS system ALC blocks) and quick construction, light shelf on every façade: To harvest and bring daylight into the building and spacious interior design: Intensive area located near the façade to utilise natural daylight.

\begin{tabular}{|lcc|}
\hline Part 5: Innovation & Allocated & Given \\
1. Innovation & 20 & 20 \\
Sub-total & 20 & $\mathbf{2 0}$ \\
\hline
\end{tabular}

Table 10. Innovation

\subsection{Results of SBTool}

The LEO building project is applied in SBTool under the operation phase. The Microsoft excel program of SBTool select the pre-installed criteria of the operation phase automatically. The scale of scores is divided between -1 and 5 , while 0 means acceptable 
practice, 3 means good practice and 5 means best practice regulated on the SBTool Ms-Excel program.

Table 11. shows individual aspects with their weights and scores. The result of total weighted score is 1.6. This result determined that LEO building sustainable performance in under an acceptable standard. Table 12 shows the graph of the performance issue area under SBTool assessment.

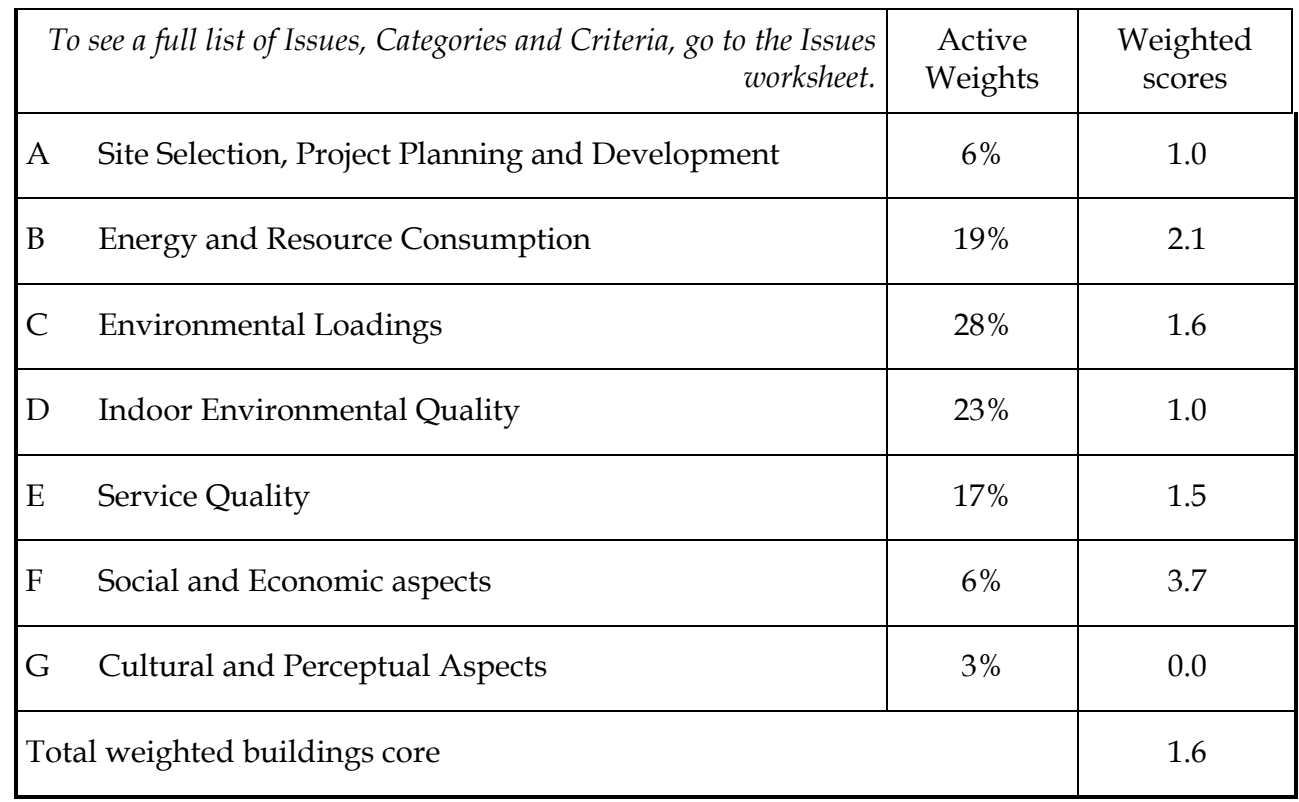

Table 11. Total weighted building scores

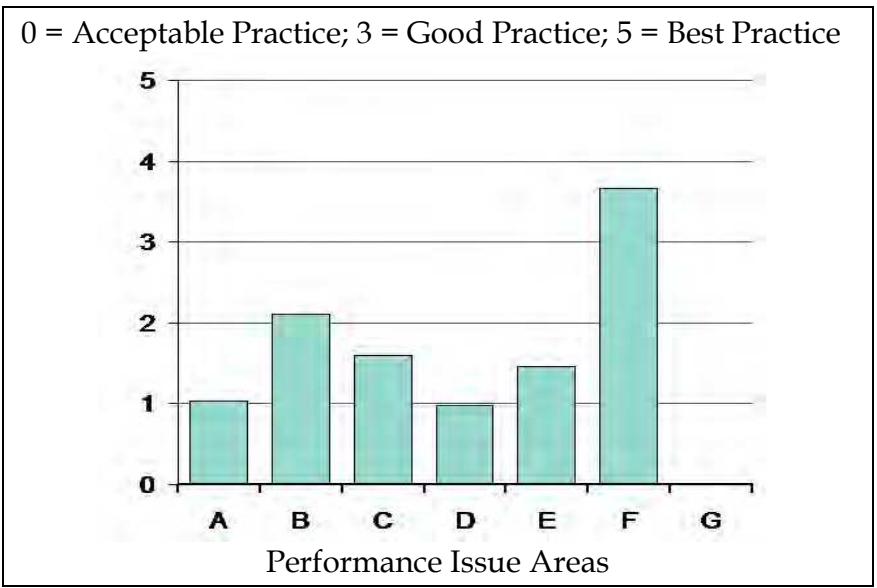

Table 12. Performance Issue Areas 
It indicates that the area F, which is Social and Cultural aspect scored the highest performance issue. The Energy and Resource Consumption issue is the second highest. The result does not show that LEO building is reflect to its design purposes as low energy building. This is due to numerous criteria and weights in the tool that could not be identify during the assessment. Due to the complexity of the tool to evaluate those criteria.

Some of the criteria needs data that which not a common practice in developing country like Malaysia such as embodied energy of the materials. This features give great impact to lower down the result under several issue.

\begin{tabular}{|l|l|l|l|}
\hline $5.6 \%$ & A & \multicolumn{2}{|l|}{ Site Selection, Project Planning and Development } \\
\hline $41.7 \%$ & A2 & \multicolumn{2}{l|}{ Project Planning } \\
\hline $66.7 \%$ & & A2.4 & Provision of surface water management system. \\
\hline $0.0 \%$ & & A2.5 & Availability of potable water treatment system. \\
\hline $0.0 \%$ & A2.6 & Availability of a split grey / potable water system. \\
\hline $33.3 \%$ & A2.7 & $\begin{array}{l}\text { Collection and recycling of solid wastes in } \\
\text { community or project. }\end{array}$ \\
\hline $0.0 \%$ & A2.8 & $\begin{array}{l}\text { Composting and re-use of sludge in the community or } \\
\text { project. }\end{array}$ \\
\hline $58.3 \%$ & A3 & Urban Design and Site Development \\
\hline $34.3 \%$ & & A3.3 & Encouragement of walking. \\
\hline $0.0 \%$ & & A3.4 & Support for bicycle use. \\
\hline $25.7 \%$ & & A3.5 & Policies governing use of private vehicles. \\
\hline $5.7 \%$ & & A3.7 & Use of native plantings. \\
\hline $22.9 \%$ & & Provision of trees with shading potential. \\
\hline
\end{tabular}

Table 13. Parameters and Weights for Project Planning and Development

\subsubsection{Site selection, project planning and development}

The result under Site Selection, Project Planning and Development (Table 13) weighted score at 1.0 points. Weights were scored for provision of surface water management system and collection and recycling of solid waste under project planning criteria. These brings the total weights for Project Planning to $2.3 \%$.While criteria under Urban Design and Site Development ,only one criteria is non applicable that is support for bicycle use. Other criteria under this issue scores $3.2 \%$ in weights. Site selection is non applicable under operation phase. 


\subsubsection{Energy and resource consumption}

However, under Energy and Resource Consumption (Table 14), the total score is the second highest among all the performance issue which is 2.1. But this score does not reflect the LEO building as Energy efficient building because the score has to be 3 and above to feature the good practice of that issue. Renewable energy criteria gives the highest weights. It is not practical to calculate the total life cycle non-renewable energy as LCC is not a common practice in Malaysia and it is skipped due to lack of data. The skipped criteria under this issue are numerous due to lack of data and several methods of assessment are difficult to understand. The formula used to calculate the energy consumption does not tally with Malaysian practice and it is skipped due to lack of data and resources.

\begin{tabular}{|c|c|c|l|}
\hline $\mathbf{1 8 . 5} \%$ & B & \multicolumn{2}{l|}{ Energy and Resource Consumption } \\
\hline $26.3 \%$ & B1 & \multicolumn{2}{|l|}{ Total Life Cycle Non-Renewable Energy } \\
\hline $0.0 \%$ & & B1.2 & $\begin{array}{l}\text { Annual non-renewable primary energy used for facility } \\
\text { operations }\end{array}$ \\
\hline $10.5 \%$ & B2 & Electrical peak demand for facility operations \\
\hline $31.6 \%$ & B3 & Renewable Energy \\
\hline $0.0 \%$ & & B3.1 & $\begin{array}{l}\text { Use of off-site energy that is generated from renewable } \\
\text { sources. }\end{array}$ \\
\hline $100.0 \%$ & & B3.2 & Provision of on-site renewable energy systems. \\
\hline $31.6 \%$ & B5 & Potable Water \\
\hline $0.0 \%$ & & B5.1 & Use of potable water for site irrigation. \\
\hline $0.0 \%$ & & B5.2 & Use of potable water for occupancy needs. \\
\hline
\end{tabular}

Table 14. Parameters and weights for Energy and Resource Consumption

\subsubsection{Environmental loading}

Issue of Environmental loadings scores 1.6 and the parameters contribute to this score are green house emission, retention of rainwater for later re-use, changes of biodiversity on site and heat island effect(Refer table 15) All of this parameters contribute to $28 \%$ weights under this issue.

Even though the weight is the highest weight, the weighted scores does not reflect the scenario. The reason is, the tool has a few numbers of file that relates to each others and formatted to get the result.

The assessor also had a very difficult moments to set the required data as the excel file provide by the inventor has several formulation problems. 


\begin{tabular}{|c|c|c|c|}
\hline $27.8 \%$ & $\mathrm{C}$ & \multicolumn{2}{|c|}{ Environmental Loadings } \\
\hline $11.4 \%$ & $\mathrm{C} 1$ & \multicolumn{2}{|c|}{ Greenhouse Gas Emissions } \\
\hline $0.0 \%$ & & $\mathrm{C} 1.2$ & $\begin{array}{l}\text { Annual GHG emissions from all energy used for } \\
\text { facility operations. }\end{array}$ \\
\hline $20.5 \%$ & $\mathrm{C} 2$ & \multicolumn{2}{|c|}{ Other Atmospheric Emissions } \\
\hline $0.0 \%$ & & $\mathrm{C} 2.1$ & $\begin{array}{l}\text { Emissions of ozone-depleting substances during } \\
\text { facility operations. }\end{array}$ \\
\hline $0.0 \%$ & & $\mathrm{C} 2.2$ & $\begin{array}{l}\text { Emissions of acidifying emissions during facility } \\
\text { operations. }\end{array}$ \\
\hline $0.0 \%$ & & $\mathrm{C} 2.3$ & $\begin{array}{l}\text { Emissions leading to photo-oxidants during facility } \\
\text { operations. }\end{array}$ \\
\hline $6.8 \%$ & $\mathrm{C} 3$ & \multicolumn{2}{|c|}{ Solid Wastes } \\
\hline $100.0 \%$ & & C3.2 & Solid waste resulting from facility operations. \\
\hline $20.5 \%$ & $\mathrm{C} 4$ & \multicolumn{2}{|c|}{ Rainwater, Stormwater and Wastewater } \\
\hline $40.0 \%$ & & C4.1 & $\begin{array}{l}\text { Liquid effluents from facility operations sent off the } \\
\text { site. }\end{array}$ \\
\hline $20.0 \%$ & & C4.2 & Retention of rainwater for later re-use. \\
\hline $40.0 \%$ & & C4.3 & Untreated stormwater retained on the site. \\
\hline $13.6 \%$ & C5 & \multicolumn{2}{|c|}{ Impacts on Site } \\
\hline $81.8 \%$ & & C5.3 & Changes in biodiversity on the site. \\
\hline $18.2 \%$ & & C5.5 & Minimizing danger of hazardous waste on site. \\
\hline $27.3 \%$ & C6 & \multicolumn{2}{|c|}{ Other Local and Regional Impacts } \\
\hline $50.0 \%$ & & C6.3 & Heat Island Effect - landscaping and paved areas. \\
\hline $50.0 \%$ & & C6.4 & Heat Island Effect - roofing. \\
\hline $0.0 \%$ & & C6.5 & Atmospheric light pollution. \\
\hline
\end{tabular}

Table 15. Parameters and weights for Environmental Loadings

\subsubsection{Indoor Environmental Quality (IEQ)}

As we can see, the score for Indoor Environmental Quality (IEQ), (Table 16), issue (1.0) is equivalent to the first issue- Project Planning and Development. However, it is different in weights as IEQ weights $23 \%$.This is because the skipped criteria in IEQ,(ventilation and noise criteria) due to lack of data, gives significant impact by lower down the result .Indoor air quality gives the highest weights as the monitoring is conducted by BEMS. 


\begin{tabular}{|c|c|c|c|}
\hline $23.1 \%$ & D & \multicolumn{2}{|c|}{ Indoor Environmental Quality } \\
\hline $36.8 \%$ & D1 & \multicolumn{2}{|c|}{ Indoor Air Quality } \\
\hline $0.0 \%$ & & D1.4 & Pollutant migration between occupancies. \\
\hline $0.0 \%$ & & D1.5 & Pollutants generated by facility maintenance. \\
\hline $0.0 \%$ & & D1.6 & Pollutants generated by occupant activities \\
\hline $0.0 \%$ & & D1.7 & $\mathrm{CO} 2$ concentrations in indoor air. \\
\hline $100.0 \%$ & & D1.8 & IAQ monitoring during project operations. \\
\hline $23.5 \%$ & D2 & \multicolumn{2}{|c|}{ Ventilation } \\
\hline $0.0 \%$ & & D2.1 & $\begin{array}{l}\text { Effectiveness of ventilation in naturally ventilated } \\
\text { occupancies. }\end{array}$ \\
\hline $0.0 \%$ & & $\mathrm{D} 2.2$ & $\begin{array}{l}\text { Air quality and ventilation in mechanically ventilated } \\
\text { occupancies. }\end{array}$ \\
\hline $0.0 \%$ & & D2.3 & Air movement in mechanically ventilated occupancies. \\
\hline $100.0 \%$ & & D2.4 & $\begin{array}{l}\text { Effectiveness of ventilation in mechanically ventilated } \\
\text { occupancies. }\end{array}$ \\
\hline $8.8 \%$ & D3 & \multicolumn{2}{|c|}{ Air Temperature and Relative Humidity } \\
\hline $50.0 \%$ & & D3.1 & $\begin{array}{l}\text { Air temperature and relative humidity in mechanically } \\
\text { cooled occupancies. }\end{array}$ \\
\hline $50.0 \%$ & O & D3.2 & Air temperature in naturally ventilated occupancies. \\
\hline $13.2 \%$ & D4 & \multicolumn{2}{|c|}{ Daylighting and Illumination } \\
\hline $0.0 \%$ & & D4.1 & Daylighting in primary occupancy areas. \\
\hline $100.0 \%$ & & $\mathrm{D} 4.2$ & Glare in non-residential occupancies. \\
\hline $0.0 \%$ & & $\mathrm{D} 4.3$ & $\begin{array}{l}\text { Illumination levels and quality of lighting in non- } \\
\text { residential occupancy design. }\end{array}$ \\
\hline $17.6 \%$ & D5 & \multicolumn{2}{|c|}{ Noise and Acoustics } \\
\hline $0.0 \%$ & & D5.1 & Noise attenuation through the exterior envelope. \\
\hline $0.0 \%$ & & D5.2 & $\begin{array}{l}\text { Transmission of facility equipment noise to primary } \\
\text { occupancies. }\end{array}$ \\
\hline $0.0 \%$ & & D5.3 & Noise attenuation between primary occupancy areas. \\
\hline $0.0 \%$ & & D5.4 & Acoustic performance within primary occupancy areas. \\
\hline
\end{tabular}

Table 16. Parameters and weights for Indoor Environmental Quality

\subsubsection{Service quality}

Under the Service quality issue (Table 17), controllability criteria gives the highest score. This is due to efficiency of building management and security system as the building is equipped with a comprehensive Building Energy Management System (BEMS) that is 
integrated with Building Control System (BCS).BEMS monitors the building energy consumption.

The total score is 1.6 and the overall weights is $18 \%$. Maintenance of operating performance criteria also contribute to the weights and scores.

\begin{tabular}{|c|c|c|c|}
\hline $16.7 \%$ & $\mathbf{E}$ & \multicolumn{2}{|c|}{ Service Quality } \\
\hline $6.4 \%$ & E1 & \multicolumn{2}{|c|}{ Safety and Security During Operations } \\
\hline $8.1 \%$ & & E1.6 & $\begin{array}{l}\text { Maintenance of core building functions during power } \\
\text { outages. }\end{array}$ \\
\hline $12.8 \%$ & E2 & \multicolumn{2}{|c|}{ Functionality and efficiency } \\
\hline $0.0 \%$ & & E2.5 & Spatial efficiency. \\
\hline $0.0 \%$ & & E2.6 & Volumetric efficiency. \\
\hline $25.5 \%$ & E3 & \multicolumn{2}{|c|}{ Controllability } \\
\hline $50.0 \%$ & & E3.1 & $\begin{array}{l}\text { Provision and operation of an effective facility } \\
\text { management control system. }\end{array}$ \\
\hline $33.3 \%$ & & E3.2 & $\begin{array}{l}\text { Capability for partial operation of facility technical } \\
\text { systems. }\end{array}$ \\
\hline $16.7 \%$ & & E3.3 & $\begin{array}{l}\text { Degree of local control of lighting systems in non- } \\
\text { residential occupancies. }\end{array}$ \\
\hline $0.0 \%$ & & E3.4 & $\begin{array}{l}\text { Degree of personal control of technical systems by } \\
\text { occupants. }\end{array}$ \\
\hline $6.4 \%$ & E4 & \multicolumn{2}{|c|}{ Flexibility and Adaptability } \\
\hline $0.0 \%$ & & E4.1 & Ability to modify facility technical systems. \\
\hline $4.3 \%$ & E5 & \multicolumn{2}{|c|}{ Commissioning of facility systems } \\
\hline $44.7 \%$ & E6 & \multicolumn{2}{|c|}{ Maintenance of Operating Performance } \\
\hline $0.0 \%$ & & E6.1 & Maintenance of building envelope performance. \\
\hline $16.7 \%$ & & E6.3 & $\begin{array}{l}\text { Development and implementation of a maintenance } \\
\text { management plan. }\end{array}$ \\
\hline $16.7 \%$ & & E6.4 & On-going monitoring and verification of performance. \\
\hline $33.3 \%$ & & E6.5 & Retention of as-built drawings and documentation. \\
\hline $16.7 \%$ & & E6.6 & Provision and maintenance of a building log. \\
\hline $0.0 \%$ & & E6.7 & Performance incentives in leases or sales agreements. \\
\hline $16.7 \%$ & & E6.8 & Skills and knowledge of operating staff. \\
\hline
\end{tabular}

Table 17. Parameters and weights for Service Quality 


\subsubsection{Social and economic aspects}

The score for Social and Economic aspects (Table 18) is 0 although the weights within all active parameters is $6 \%$. The weightage for this criteria -Access to views from work areas is too little to derive score for this aspect.

\begin{tabular}{|l|l|l|l|}
\hline $\mathbf{5 . 6 \%}$ & F & \multicolumn{2}{l|}{ Social and Economic aspects } \\
\hline $20.0 \%$ & F1 & \multicolumn{2}{l|}{ Social Aspects } \\
\hline $0.0 \%$ & & F1.6 & Access to views from work areas. \\
\hline $80.0 \%$ & F2 & Cost and Economics \\
\hline $0.0 \%$ & & F2.1 & Minimization of life-cycle cost. \\
\hline $0.0 \%$ & & F2.3 & Minimization of operating and maintenance cost. \\
\hline $0.0 \%$ & & F2.5 & Support of Local Economy. \\
\hline $100.0 \%$ & & F2.6 & Commercial viability \\
\hline
\end{tabular}

Table 18. Parameters and weights for Social and Economic aspects

\subsubsection{Cultural and perceptual aspects}

This scenario is also identical to the Cultural and Perceptual aspects (Table 19) where the weights is $3 \%$ and scores is 0 . This is due to common practice in Malaysia of not covering required parameter.

\begin{tabular}{|c|c|l|l|}
\hline $\mathbf{2 . 8} \%$ & G & \multicolumn{2}{l|}{ Cultural and Perceptual Aspects } \\
\hline $100.0 \%$ & G1 & \multicolumn{2}{l|}{ Culture \& Heritage } \\
\hline $0.0 \%$ & & G1.3 & Maintenance of heritage value of existing facility. \\
\hline
\end{tabular}

Table 19. Parameters and weights for Cultural and Perceptual Aspects

Some of the practices are available but the method of calculation contribute to lack of data required. As a result, the criteria has to be skipped off from the list.

\section{Overall comparison}

As to compare both tools issue and criteria, experts review have been achieved from the construction industry professionals. They are selected from their expertise in various fields of the issues and criteria of both tools.

The result of both tools has been presented to them to get their feedback on the suitability of the tool to be adopted in Malaysia. Their reviews are based on the current practices in Malaysia. 
Table 20 shows the overall result of both tools. It shows the differences and the percentage of scoring on every issues.

\begin{tabular}{|c|c|c|c|c|c|c|}
\hline \multicolumn{3}{|c|}{ GREEN MARK } & \multicolumn{4}{|c|}{ SBTOOL } \\
\hline & Scores & Percentage & $\begin{array}{l}\text { To se } \\
\text { Issue } \\
\text { Crite } \\
\text { worl }\end{array}$ & $\begin{array}{l}\text { a full list of } \\
\text { Categories and } \\
\text { ia, go to the Issues } \\
\text { heet. }\end{array}$ & $\begin{array}{l}\text { Active } \\
\text { Weights }\end{array}$ & $\begin{array}{l}\text { Weighted } \\
\text { scores }\end{array}$ \\
\hline $\begin{array}{l}\text { Part 1: Energy } \\
\text { Efficiency }\end{array}$ & $25 / 25$ & $100 \%$ & A & $\begin{array}{l}\text { Site Selection, } \\
\text { Project Planning } \\
\text { and Development }\end{array}$ & $6 \%$ & 1.0 \\
\hline $\begin{array}{l}\text { Part 2: Water } \\
\text { Efficiency }\end{array}$ & $7 / 15$ & $46.6 \%$ & B & $\begin{array}{l}\text { Energy and } \\
\text { Resource } \\
\text { Consumption }\end{array}$ & $19 \%$ & 2.1 \\
\hline $\begin{array}{l}\text { Part 3: Building } \\
\text { Management \& } \\
\text { Operation }\end{array}$ & $16 / 25$ & $64 \%$ & $\mathrm{C}$ & $\begin{array}{l}\text { Environmental } \\
\text { Loadings }\end{array}$ & $28 \%$ & 1.6 \\
\hline $\begin{array}{l}\text { Part 4: Indoor } \\
\text { Environmental } \\
\text { Quality and } \\
\text { Environmental } \\
\text { Protection }\end{array}$ & $13 / 15$ & $86.6 \%$ & $\mathrm{D}$ & $\begin{array}{l}\text { Indoor } \\
\text { Environmental } \\
\text { Quality }\end{array}$ & $23 \%$ & 1.0 \\
\hline \multirow[t]{3}{*}{$\begin{array}{l}\text { Part 5: } \\
\text { Innovation }\end{array}$} & $20 / 20$ & $100 \%$ & $\mathrm{E}$ & Service Quality & $17 \%$ & 1.5 \\
\hline & & & $\mathrm{F}$ & $\begin{array}{l}\text { Social and } \\
\text { Economic aspects }\end{array}$ & $6 \%$ & 3.7 \\
\hline & & & G & $\begin{array}{l}\text { Cultural and } \\
\text { Perceptual } \\
\text { Aspects }\end{array}$ & $3 \%$ & 0.0 \\
\hline Total score & $81 / 100$ & & \multicolumn{3}{|c|}{ Total weighted building score } & 1.6 \\
\hline
\end{tabular}

Table 20. Total scores for Green Mark and Total weighted building scores for SBTool

\subsection{Expert review on Green Mark}

The Green Mark Assessment method is getting the higher acceptance by the reviewers because it is straight forward and easy to carry out the assessment. The assessment duration is only one(1) day. The issue, criteria and parameters are very comprehensible in description and understood by all the reviewers. They can determined the sequence of the scores from the assessment sheet given. Overall scores are derived from the clear descriptions of each parameter. It is also easy to determine the components to be accessed and expertise needed as the descriptions and the marks given are clearly stated. 
The assessment for Part 1-Energy efficiency achieved a full scores due to similarity in codes of practices. Energy efficiency and use of renewable energy is a central part of any environmental labelling system. In addition, in many countries, energy efficiency is part of mandatory regulations for new buildings. In those countries, the minimum standards for energy efficiency for new buildings will constitute the minimum standard in the labelling scheme, and levels above that contributes to achieve a higher scoring that 'Just Certified' will be defined.

In Malaysia, the Malaysian Standard for Energy Efficiency and use of Renewable Energy, MS 1525:2007, will become part of the Uniform Building By-Laws in 2008, as the Ministry of Housing and Local Government is expected to table a law in parliament to that effect. Under energy efficiency index, the minimum performance for office building required by Singapore practice is 240 to $220 \mathrm{kWh} / \mathrm{m} 2 / \mathrm{yr}$. This index is similar to MS 1525 standard.

From expert reviews, Air Conditioning systems and Lighting Systems shall comply with SS 530 Code of Practice for Energy Efficiency Standard for Building Services and Equipment Ventilation compliance to SS CP 13 Code of Practice for Mechanical Ventilation and AirConditioning Standards for Air Tightness and Leakage. Electrical sub-metering Luminance Level according to Code of Practice for Workplaces, SS 531:Part 1 : 2006. Green Mark Goldplus at least 25\% energy savings and Green Mark Platinum: at least 30\% energy savings. The LEO building has fulfilled the above requirements.

The Environmental Thermal Transmission Value (ETTV) cannot exceed $50 \mathrm{~W} / \mathrm{m}^{2}$. There are maximum U-values for the roof $(0.5 \mathrm{~W} / \mathrm{m} 2 \mathrm{~K}$ for light roofs) two points for every $1 \mathrm{~W} / \mathrm{m} 2$ in ETTV improvement. Extra points are given for reduction west façade walls and windows, and improvement of the roof insulation above base level. Extra points are also given for natural ventilation of car park, for improved electric lighting efficiency, improved ventilation of common areas and improved efficiency of lifts and escalators. Another extra points given by reviewer for improvement of the chillers' efficiency, the Unitary Air Conditioning efficiency and air distribution efficiency above minimum standard.

Points also given for other Energy Efficiency practices, such as using motion sensors, daylight pipes, heat recovery systems etc. Renewable Energy in the building was given up to 20 points, 5 points for each $1 \%$ of electricity consumption covered by Renewable Energy. The reviewers found that Green Mark Assessment method is suitable to be understand by building owner in Malaysia. The reason given by them is the practicality of the method (easy identification of features and points), saving time and cost efficiency .This tool also reflect the LEO building as an energy efficient building as derived by the results.

For other Part such as water efficiency, building management and operation, Indoor environmental quality and Innovation, reviewers agreed that Malaysia has to improve performance on those parts. This is due to the lack of maintenance practices and lack of requirement by statutory bodies. They suggested that the comprehensive guidelines on sustainable building must be taking into place before the assessment could be made.

\subsection{Expert review on SBTool}

Overall comments from the reviewers are the difficulties to understand the flow and how to aggregate data. It is also complicated because this assessment method needs a wide range of 
experts and ample of time must be given to access the parameter. It takes about 3 weeks to collect data and complete the assessment and another week to compute the result. This is because of several adjustment and more information have to be synthesised to evaluate the result. So, time consuming made the tool less favourable among the experts.

The complicated structure of the tool made the assessor confuse and tend to misleading the assessment. This is because all the related Microsoft Excel files for the said tool have to be opened simultaneously. If the assessor fail to do so, the data that keyed into the file cannot be linked and the expected result will be faulty. There are too many criteria to be assess. It seems to be comprehensive but this made the assessment work complicated.

Furthermore, in SBTool, the score gained under each criteria does not reflex the final result. This is because, the score has to be multiple with the weigh tage under each criteria to get the final score. Even though the score is higher but the weightage is lowed, overall result will still be low. The significant of the achievement will be controlled by the weightage. The weightage plays an important roles determining the score of the criteria. However, the expert collective agreement conclude that it is difficult to set the weightage as the data for each criteria must be easy to obtain. Unfortunately, Malaysia lack of the important data needed to form the weightage.

According to Nil Larsson, the result of SBTool, which is +1 is good. This assessment can be a yardstick to evaluate the environmental performance of an office building in Malaysia. Further studies can be done to unveil on the non complaint issue of SBTool on LEO building. This will help to develop a comprehensive rating system that recognise worldwide.

\subsection{The non-compliance criteria}

The non-compliance criteria were identified from the above result. The Green Mark only have one non-compliance criteria to Malaysian building practice - Indoor Air Quality Audit. The SBTool non compliance criteria covers of seven aspect framework from Project Planning and Development, Energy and resource consumption, Environmental loadings, Indoor Environmental quality, Service Quality, Social and economic aspects, Cultural and perceptual aspects. As we can see from the result, SBTool key component have a significant number of sustainable features evaluated comparing to Green Mark and the SBTool framework are comprehensive. The SBTool system is a rating framework or toolbox, designed to allow countries to design their own locally relevant rating systems. SBTool is designed to include consideration of regional conditions and values, in local languages, but the calibration to local conditions does not destroy the value of a common structure and terminology. These key components of SBRS are the critical features to evaluate sustainable building. They are the factors that need attention from the building owner for determining the sustainability of their office building. Further studies can be done to identify the factors of non-compliance criteria of SBRS for Malaysian building from SBTool and to calibrate the tool to local conditions.

\subsection{Findings of evaluation result}

The overall result, explain the effectiveness of the selected SBRS tools. From the overall result it is findings that the effectiveness of the evaluation procedure can be achieve through: 
i. Adapting the applicable tool to local use. This can save time and cost of developing new tools. Furthermore, the result can be used to develop more localise tools.

ii. Cost effective-Identify the cost of using a system, including cost for use or rating system materials, cost of project registration, fees associated with certification.

iii. Ease of Use for local expert: Complexity of the tools and technical knowledge needed to complete rating system process, especially for the optimization of energy use, environmentally preferable products use, and indoor environmental quality enhancement.

iv. Save time- time typically needed to complete the assessment from registration, application and result.

v. Product support: Availability and responsiveness of direct requests for assistance, availability of training, and usability of information available on the website, through case studies, documented inquiries, and frequently asked questions.

vi. The structure of the SBRS tools can be adapted to local context - the issues, criteria and benchmark must be comprehensive and suit the local context or can be customised to local contact.

vii. The criteria of assessment is understandable by local expert and common practice of the industry-e.g. energy policy.

viii. The procedure of interpreting the scores given must be easy to derive.

ix. The knowledge and skills of building expert on the building environmental practice and current technologies of sustainable building performance. e.g., materials use, use of recycle material, embodied energy of the material used, etc. Building expert also must develop skills on the use of SBRS Tools.

$\mathrm{x}$. Building industry practice - develop more code of practice on building sustainability issues.

xi. Research and development by local universities on the absent data such as embodied energy of material used, biodiversity, etc.

\section{In-depth interview analysis}

The aim of this study is to explore the SBRS issues and implementation in Malaysia building industry. The use of in-depth interview with the building expert enable the study to get a clear picture of what is actual phenomena in the real situation. To explore the current issues, the issues are discussed under the following heading:

i. Moving into sustainability practice

ii. Understanding on SBRS issue

iii. Factors that influent the implementation

iv. Encouragement to existing building stock

\subsection{Interview questions responses}

\section{Participant 1}

The first participant is a consultant architect with few sustainable building project being awarded in recent years and he is one of the GBI certifier. He has been involved in sustainable building practice since year one of his undergraduate studies in Australia. So, according to him, sustainable building practice is not a new issue but recently gaining 
importance due to climate change, $\mathrm{CO} 2$ emission and other environmental impact to the building. Due to this , he directs his work to provide sustainable building features seriously for the past five years and involves in SBRS implementation for Malaysian building.

He said that all SBRS issue are important to reach building sustainability, resulting in him to covering all the important issues when he designed a building. He stated that SBRS will be successful in Malaysia due to strong support by the government, industry and public. The Malaysian government gives full support to the SBRS implementation by giving tax reduction to certified building and many incentives to the building developers, property owners and publics. In Malaysia, the government driven by the public but in Singapore the government push the public to implement SBRS. As he said, GBI received strong support from the industry with forty over building had submitted their registration for GBI certification. He believed that by end of 2009, there will be more building certified as for now (September 2009) one building had been certified (Pusat Tenaga Malaysia).

As to encourage the existing building stock to become sustainable, he believes that education is the key. He says that we must educate the existing building owners on the benefits and cost reduction when we reduce the BEI of (Building energy index) the building. The GBI rating system currently assess new building only but he said that the new SBRS for existing buildings will be issue in the middle of next year. He also says that the green technology never affected by the economic crisis .As for Malaysia, major developers such as Sime Darby, Sunway, support SBRS by implementing the sustainability features to their projects and registered for GBI certification.

\section{Participant 2}

The second participant is also a professional architect and GBI certifier. He says that SBRS is a system that will show us how building performed over time. In the long run, it will save energy, money ,investment and also environment. He has been involved in sustainable design since his college days.

His sustainable building design knowledge improves during training on site. He tries to make the sustainable building to comply as to design a building that kind to environment. He says that, SBRS in Malaysia start 1 1/2 years ago with the assistant of IEM (Institute of Engineer Malaysia). After a year they came up with GBI. Before that MIA, IEM and BCA Singapore worked together to modelled GBI. But, GBI differ from Green Mark because in term of geographical area, Singapore is small and more efficient whereas Malaysia is larger and having many authorities that control the building practice.

He says that Malaysian government under the Ministry of Finance supports Green technology. Under GBI, the last issue discussed is Innovation, designers can come out with any idea that they think appropriate to make the building more sustainable. Government encouragement of sustainable building issue is very important. They try to make MS1525 mandatory as a benchmark for minimum standard of energy efficiency. This will be incorporated with Uniform Building By Law.

He added that industry must drive the SBRS. Developers must develop sustainable building and certified GBI and public will help in term of buying the certified property. As in Singapore and Australia, the certified building will get higher rental rate. This is proven through the good indoor environmental quality that improve the productivity and quality 
of health. This is what we can educate our existing building owners. The cost of sustainable building is higher but we can get more benefits .But the problem facing by Malaysia is inefficiency of our public transport. The building is located quite far and not a walking distance from public transport. This makes the designer having the needs to provide more parking space. Due to this situation, traffic jam is the main problem in the city. So according to him, a lot more we have to do to educate client, owners, government and public in terms of sustainability. Government must promote and encourage people to buy sustainable building and also make the people change their lifestyle towards green issue and energy saving.

He agree that SBRS can be successful in Malaysia due to the great interest from government authority . Almost every week, various government departments requested the GBI certifier to give talks on the new SBRS. This seems to contribute to more educated people on the SBRS issue.

\section{Participant 3}

The third participant is the building energy manager. He has over 10 years experience with sustainable building and SBRS issues. According to him, energy efficiency and sustainable features are interrelated. The government first designed the Leo building to implement the MS1525 and to make it as a showcase to the public on the sustainable building features. This is to promote sustainable building as a practice and to show that MS 1525 code of practice can be achieved. He said that SBRS can help to measure the performance of sustainable building. It is an appropriate yardstick as it covers almost all related issues of sustainable building. The main important features to him is energy efficiency. As the government through PTM (Pusat Tenaga Malaysia) promoted Suria 1000, the solar panel for residential housing, it was totally sold out within a short period. This phenomenon shows that the acceptance of the public on the sustainable building is very great. But he says education is still important as this situation only reflects to the well known developer that encourage sustainable development in their building projects. Understanding sustainable features is very important in order to implement the SBRS. We have to educate the building industry player on the advantages of SBRS certification to their building. Cost is a very important issues in construction. If they realise that sustainable building can reduce their maintenance cost and increase rental income, we don't have to force them to implement the sustainable features. They will do it on voluntarily. This will also encourage the owner of existing building stock to implement sustainable features on their building.

In his opinion, government support is the most important means of promoting SBRS. Malaysian government gives full support on sustainable issues by giving more and more incentives to the building that will be certified by GBI later. This will ensure the successful of SBRS implementation in Malaysia.

\subsection{Moving into sustainability practice}

The participants have been practising sustainable building design since undergraduate studies. According to participant 1, recent scenario on the climate change had directed them into sustainable building practice. This is due to the minimizing the environmental impact of the building and green issues that promoted worldwide. Participant 2, said that his knowledge on sustainable building improved during his training on site. The practice make 
sure that the building comply to the sustainable standard that kind to the environment. Whereas, participant 3 is a building energy manager. His nature of work put him into the strong practice of sustainability.

\subsection{Understanding on SBRS issue}

All participants agree that understanding SBRS issue is important in order to promote SBRS to Malaysian building. Participant 1 agree that the industry is driven by the public. The public request for sustainable building to be develop and they need the tools to measure the performance of the building. So, SBRS is a yardstick to measure the building sustainability performance. All participants agree that understanding of SBRS issues can be achieved through education.

\subsection{Factors that influent the implementation}

According to participant 1,SBRS will be successful due to the strong support by the government, industry and the user. The Malaysian government plans to give tax reduction and more incentives for certified building. Strong support from the industry with over 40 building project registered for certifications also shows that SBRS will be successfully implemented in Malaysia. He ends with the statement that current economic crisis never affects green technology. This is due to a very good respond from the reputable developer in Malaysia like Sime Darby and Sunway to certified their building projects recently. Likewise, the remaining participants also agree with the first participant statement. Participant 3 added that encouragement by government to use alternative energy sources like providing solar panel at subsidised rate is very supportive. But according to participant 2 , the current development of transportation in Malaysia is quite discouraging. The public transportation is not located within walking distance to the building. This will discourage the public from using the public transport. The use of more vehicle will increase the $\mathrm{CO} 2$ emission and contribute to global warming. But, according to him, the government interest in SBRS is very encouraging where various of departments asking for GBI talks almost every week. This phenomena will enhance their knowledge and acceptance of SBRS.

\subsection{Encouragement to existing building stock}

Participant 1 says that education is the key to encourage the existing building stock owners to implement SBRS. We must explain to them the benefits of reducing the BEI (Building Energy Index) to the maintenance cost of the building. Participant 2 and 3 also agree with the first respondent that by explaining the benefit of sustainable building and giving them example of successful building, the building owners will voluntary implement the features. Their investment is very important and to prolong the steady income, they have to be courageous to change the thought. All the participants added that with the new existing building tool that will come out in 2010, the existing building owner will be more encourage to invest in sustainability.

\subsection{Findings on the effect of SBRS implementation}

The finding of this section uses logic models evaluation (Figure 4.3). Joseph Wholey (1979) who is at the forefront in developing logic models as an analytical technique. The logic 
model deliberately stipulates a complex chain of event over time (Yin,2003). The event are staged in repeated cause effect-cause-effect patterns, whereby a dependant variable (event) at an earlier stage become the dependant variable(causal event) for the next stage(Peterson \& Bickman,1992; Rog \& Huebner,1992).

Figure 1 illustrate the integration of government support, building industry support and public awareness in implementing sustainable building rating system for Malaysian building.

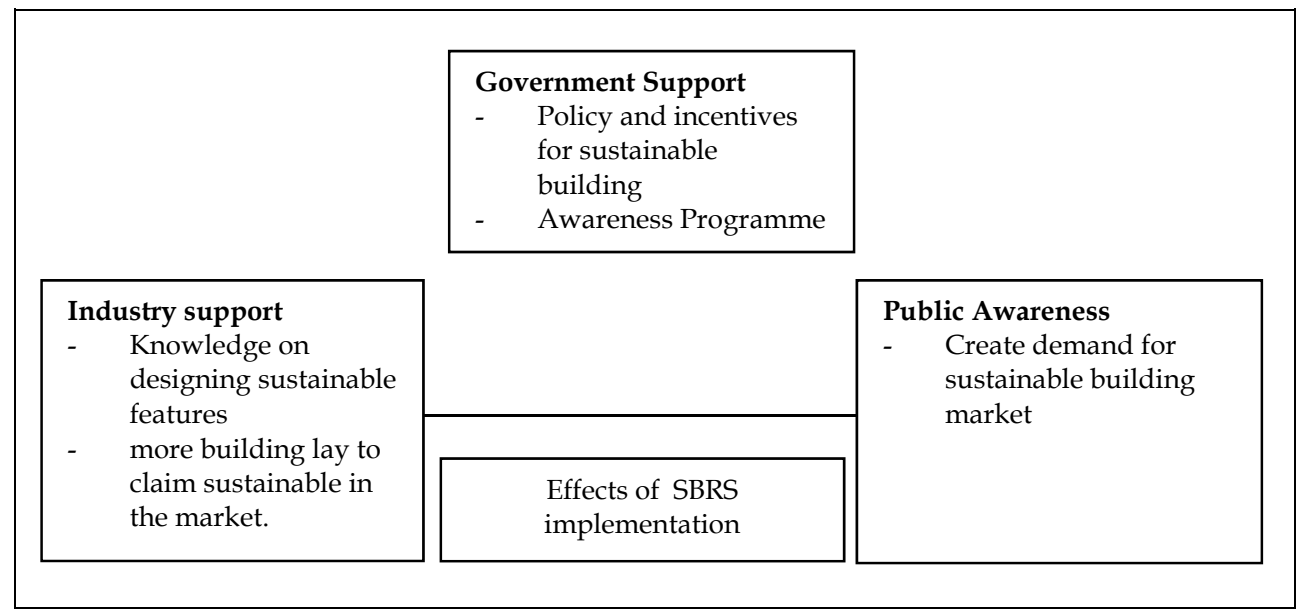

Fig. 1. The scenario of Malaysian building industry.

The overall outcome for this study is illustrated in figure 2 using logic model. The researcher begin the study with three sources of data from the scenario of Malaysian building industry, building assessment to LEO Building and interviews with the building industry player that expert in SBRS. Expert review are conducted to validate the result. The objectives of the assessment are to test the adaptability of SBRS to Malaysian building using existing office building version. This is to provide knowledge and understanding on the implementation issues arise. The compliance criteria are able to identify Malaysian building current practice that comply to the SBRS criteria. The non-compliance criteria are able to identify the required criteria which is absent in Malaysian building industry practice. This is called The precursory outcome.

The intermediate outcome from the study is the change in practice by the Malaysian building industry, resulting for more issues and criteria to be considered for designing sustainable building and development of rating system for existing building. The intermediate outcome is the change of benefit to the industry and public, resulting market demand for sustainable building. This will also effect the external market condition in Asia.

The later outcome is the change in sustainable building industry market resulting more building in Malaysia eager to claim for sustainable building. This will also change the public benefit, resulting economic development and public policy outcome for SBRS implementation. The later outcome will also effect the external market condition for Malaysia to compete in Asian SBRS market by 2013. The whole outcome is the model of 


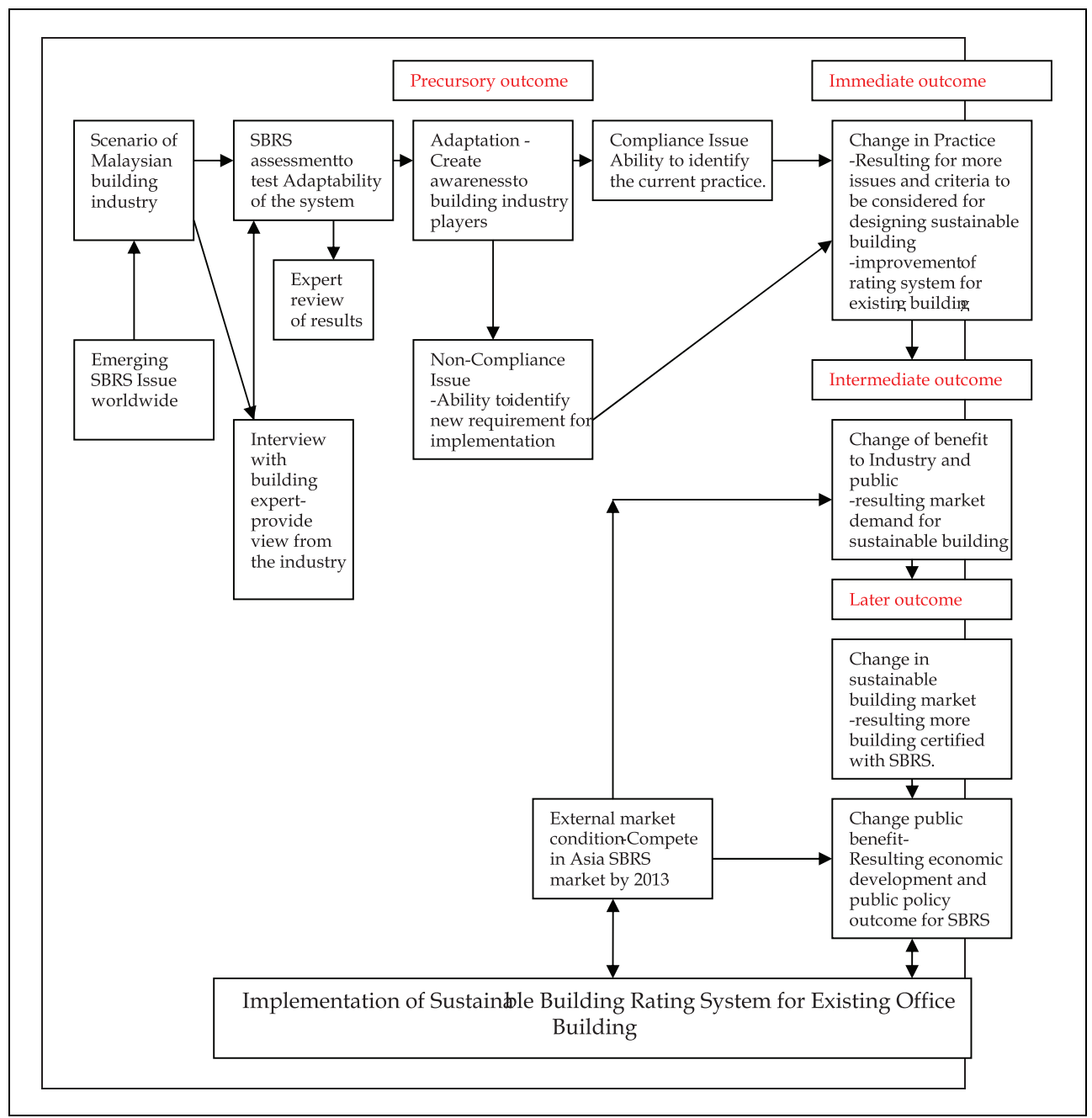

Adapted from Yin and Oldsman (1995)

Fig. 2. The effect of SBRS Tools implementation for existing office buildings.

changes in the Malaysian building industry that support the implementation of sustainable building rating system. The models shows the effects of SBRS implementation on Malaysian office buildings;

i. Adaptation of SBRS create awareness to Malaysian building industry players.

ii. The compliance issues enable us to identify the current practice that complies to international standard.

iii. The non-compliance issues enable us to identify new requirement needed in order to comply with international standard. 
iv. Those issues b) and c) will result in changes in practice; more issues and criteria to be considered for designing sustainable building - improvement of rating system for existing building.

v. The change in practice will benefit the industry and public; this will create market demand for sustainable building.

vi. The effect of demand for sustainable building will result for more building certified with SBRS to cater for sustainable building market.

vii. Demand for sustainable building will result public policy outcome for SBRS as the public are aware of the benefit.

viii. The later effect will able be to competent to external market, Malaysia to compete in Asian SBRS market by 2013.

\section{Conclusion}

As the conclusion, the comparison on both SBRS are made using three approach- Theoretical Comparison Analysis, Evaluation comparison analysis and Overall Comparison. Under Theoretical Comparison Analysis, both SBRS are compared based on the essence of the SBRS and how the SBRS evaluates sustainability. This framework is used to give better understanding of the SBRS structure with academically recognised terminology and methodology. The evaluation comparison analysis as a means of collecting, analyzing, calculating data to get all the criteria scored. On the other hand, overall comparison is carried out to compare both tools issue and criteria, by experts review from the construction industry professionals. As the conclusion for the interviews, the researcher explores the current issues, and discussed under the following heading:

i. Moving into sustainability practice

ii. Understanding on SBRS issue

iii. Factors that influent the implementation

iv. Encouragement to existing building stock

From the result and experts review, it is define that the structure of the tools will contribute to the understanding of how the tool evaluate sustainability. The finding of this study uses logic models for identifying the effects in implementing SBRS in Malaysia. The overall result, explain the effectiveness of the selected SBRS tools. From the overall result it is discovered that the effectiveness of the evaluation procedure can be achieve through adapting the suitable SBRS tools, expert knowledge and understanding on the evaluation procedure, construction industry practice and acceptance by the stakeholder.

\section{References}

Al Waer, H., \& Sibley, M. (2005). Building Sustainability Assessment Methods: Indicators, Applications, Limitations and Development Trends. Paper presented at the Conference on Sustainable Buiding South East Asia, Kuala Lumpur, Malaysia.

Buchan, Susan; M. Arch; Yves Khawam.(2008) "The case for regionalization: an evaluation of green building rating systems.(SUSTAINABLE HOME)." Environmental Design \& Construction. BNP Media. Retrieved August 22, 2010 from HighBeam Research: http:/ / www.highbeam.com/doc/1G1-180281610.html 
Bullen, P. A. (2007). Adaptive reuse and sustainability of commercial buildings. FacilitiesVol. 25 (No. 1/2), pp. 20-31.

Chung, W. Y. (2005). Comparison of Two Sustainable building assessment tools applied to Holmen project in Stockholm, MSc Thesis. Unpublished MSc, Royal Institute of Technology, Stockholm, Sweden.

Cohen, R., Standeven, M., Bordass, B., \& Leaman, A. (2001). Assessing Building Performance in Use 1: the Probe process. Building Research \& Information, 29(2), 85-102.

Cole, R. J. (2001). A building environmental assessment method for British Columbia. Final report to BC Green Building Ad-Hoc Committee. http://www.buildsmart.ca/pdfs/ASSESSMENT\%20REPORT.PDF

Cole, R. J. (2001). Lessons learned, future directions and issues for GBC. Building Research \& Information, 29(5), 355-373.

Cole, R. J., \& Larsson, N. K. (2002). GBC 2002 GBTool User Manual. Retrieved 20/3/06, http://greenbuilding.ca/

Colker, Ryan M.(2009)"Why we need a labeling program.(Q\&A)." ASHRAE Journal. American Society of Heating, Refrigerating, and Air-Conditioning Engineers,. Retrieved August 22, 2010 from HighBeam Research: http://www.highbeam.com/doc/1G1-222316036.html

Creswell, J. W. (2003). Research Design: Qualitative, Quantitave and mixed methods Approaches: Sage Publication.

Creswell, J. W. (2007). Qualitative Inquiry \& Research Design: Choosing Among Five Approaches, Sage Publication.

CSIR Boutek. (2003). The Sustainable Building CD: User Manual (Version 1).Retrieved 25/4/2006, http:/ / www.sustainablebuildings.co.za/index.htm

Davies, Hywel.(2009) "Energy labeling in the UK: it's the law." ASHRAE Journal. American Society of Heating, Refrigerating, and Air-Conditioning Engineers,. Retrieved August 22, 2010 from HighBeam Research: http://www.highbeam.com/doc/1G1-222316038.html

Elisa Campbell Consulting. (2006). Assessment of tools for rating the performance of existing buildings: A report on the options.

Faridah Shafii, Z. A. A., Mohamed Zahry Othman. (2006). Achieving Sustainable Construction in Developing Countries of Southeast Asia. Paper presented at the The 6th Asia-Pacific Structural Engineering \& Construction Conference(ASPEC 2006), Kuala Lumpur, Malaysia.

Gibberd, J. (2003). Integrating Sustainable Development into Briefing and Design Processes in Buildings in Developing Countries: An Assessment Tool. Unpublished PhD, University of Pretoria.

Gowri, K. (2004). Green Building Rating Systems: An Overview. ASHRAE Journal, November 2004, 56-60.

Henrikke Baumann, S. J. C. (1999). An Evaluative Framework for Conceptual and Analytical Approaches Used in Environmental Management. Greener Management International, 26(Summer 1999), 109-122.

Jarnagin, Ronald E.. Inc.( 2009) "Program will help owners, operators assess buildings and guide good decisions.(Building Energy Quotient rating program)." ASHRAE Journal. American Society of Heating, Refrigerating, and Air-Conditioning Research. 22 Aug. 2010 http://www.highbeam.com>. 
Kats, G., L.Alevantis, A. Berman,E.Mills and J.Perlman. (2003). The cost and financial benefits of Green Buildings: Report to California 's Sustainable Task Force.

Larsson, N. K., \& Cole, R. J. A Second-Generation Environmental Performance Assessment System for Buildings. Green Building Challenge '98 Conference Retrospective. Retrieved 21/04/2006, from http://greenbuilding.ca/gbc98cnf/speakers/larsson.htm

Longoria, K. T. a. R. (2007). The Green Braid:Towards an architecture of ecology, economy and equity. London \& New York: Routledge.

Lowe, M. B. R. (2006). Building regulation and sustainable housing.Part1:A critique of Part L of the Building regulation 1995 for England and Wales. Structural Survey, 18(1), pp28-37.

Maria Sinou, S. K. (2006). Present and future of building performance assessment tools. Management of Environment, 17(5,2005), 570-586.

Mark Deakin, G. M., Peter Nijkamp and Ron Vreeker. (2007). Sustainable Urban Development (1st ed. Vol. 2). London \& New York: Routledge

McGraw-Hill. (2008). Smart Market Report.

Merriam, S. B. (1991). Case Study Research in Education:A Qualitative Approach. San Francisco: Jossey Bass Publisher.

Nall, Dan. (2009). "How building EQ works: two rating systems share similar scale.(building energy quotient)." ASHRAE Journal. American Society of Heating, Refrigerating, and Air-Conditioning Engineers, Retrieved August 22, 2010 from HighBeam Research: http://www.highbeam.com/doc/1G1-222316037.html

Peter A.Bullen, (2007).Adaptive reuse of sustainability of commercial building. Journal of Facilities, Vol 25,No1/2,pp 20-31.

Reed, M. S., Fraser, E. D. G., \& Dougill, A. J. (2005). An adaptive learning process for developing and applying sustainability indicaotrs with local communities. Ecological Economics.

Sassi, P. (2006). Strategies for Sustainable Architecture (1st ed.). Abingdon.Oxon: Taylor \& Francis.

Steven Curwell, M. D. a. M. S. (2006). Sustainable Urban Development Volume 1:The Framework and Protocols for Environmental Assessment (Vol. 1st). London \& New York: Routledge.

Szokolay, S. V. (2004). Introduction to Architectural Science:The Basis of Sustainable Design .Amsterdam. Boston.Heidelberg.London.New York.Oxford.Paris.San Diego.San Francisco.Singapore.Sydney.Tokyo: Architectural Press-Elsevier.

Todd, J. A., Crawley, D., Geissler, S., \& Lindsey, G. (2001). Comparative assessment of environmental performance tools and the role of the Green Building Challenge. Building Research \& Information, 29(5), 324-335.

Yin, R. K. (2003). Case Study Research: Design and Method. London: Sage Publication.

Zalina Shari, M. F. Z. J., Elias Salleh, Lim Chin Haw. (2008). The Potential of sustainable building rating System in the Malaysian building industry. International Journal of Sustainable Tropical Design Research and Practice, 3(1), 3-14. 


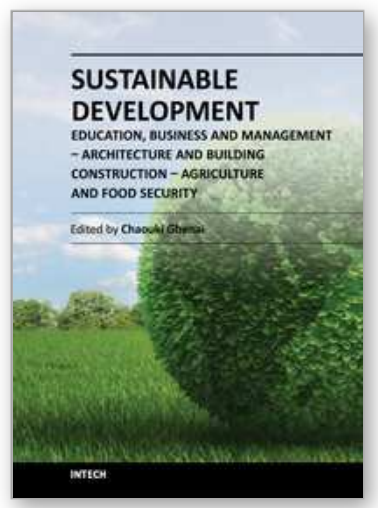

\author{
Sustainable Development - Education, Business and Management \\ - Architecture and Building Construction - Agriculture and Food \\ Security \\ Edited by Prof. Chaouki Ghenai
}

ISBN 978-953-51-0116-1

Hard cover, 342 pages

Publisher InTech

Published online 07, March, 2012

Published in print edition March, 2012

Securing the future of the human race will require an improved understanding of the environment as well as of technological solutions, mindsets and behaviors in line with modes of development that the ecosphere of our planet can support. Some experts see the only solution in a global deflation of the currently unsustainable exploitation of resources. However, sustainable development offers an approach that would be practical to fuse with the managerial strategies and assessment tools for policy and decision makers at the regional planning level. Environmentalists, architects, engineers, policy makers and economists will have to work together in order to ensure that planning and development can meet our society's present needs without compromising the security of future generations. Better planning methods for urban and rural expansion could prevent environmental destruction and imminent crises. Energy, transport, water, environment and food production systems should aim for self-sufficiency and not the rapid depletion of natural resources. Planning for sustainable development must overcome many complex technical and social issues.

\title{
How to reference
}

In order to correctly reference this scholarly work, feel free to copy and paste the following:

Ar Zuhairuse MD Darus and Nor Atikah Hashim (2012). Sustainable Building in Malaysia: The Development of Sustainable Building Rating System, Sustainable Development - Education, Business and Management Architecture and Building Construction - Agriculture and Food Security, Prof. Chaouki Ghenai (Ed.), ISBN: 978953-51-0116-1, InTech, Available from: http://www.intechopen.com/books/sustainable-developmenteducation-business-and-management-architecture-and-building-construction-agriculture-and-foodsecurity/sustainable-building-in-malaysia-the-development-of-sustainable-building-rating-system

\section{INTECH}

open science | open minds

\author{
InTech Europe \\ University Campus STeP Ri \\ Slavka Krautzeka 83/A \\ 51000 Rijeka, Croatia \\ Phone: +385 (51) 770447 \\ Fax: +385 (51) 686166 \\ www.intechopen.com
}

\author{
InTech China \\ Unit 405, Office Block, Hotel Equatorial Shanghai \\ No.65, Yan An Road (West), Shanghai, 200040, China \\ 中国上海市延安西路65号上海国际贵都大饭店办公楼405单元 \\ Phone: +86-21-62489820 \\ Fax: $+86-21-62489821$
}


(C) 2012 The Author(s). Licensee IntechOpen. This is an open access article distributed under the terms of the Creative Commons Attribution 3.0 License, which permits unrestricted use, distribution, and reproduction in any medium, provided the original work is properly cited. 